\title{
Rheological parameters of some soil samples before and after $\mathrm{H}_{2} \mathrm{O}_{2}$ treatment
}

DoLgor KHAYDAPOVA - Department of Soil Science, Lomonosov Moscow State University - dkhaydapova@yandex.ru LIESL WIESE - Department of Soil Science, Stellenbosch University ANDREI ROZANOV - Department of Soil Science, Stellenbosch University EvgENY MILANOVSKIY - Department of Soil Science, Lomonosov Moscow State University Érkezett: 2017. 11. 19. - Received: 19. 11. 2017. - https://doi.org/10.14382/epitoanyag-jsbcm.2018.8

\section{Abstract}

The effect of soil organic matter (SOM) on formation of inter-particle bonds was studied in soils with high organic and no mineral carbon content in the top (A1, Ap) layers of different origin and under various land uses. The first set of soil samples was collected in the Alekhin Central Chernozem Reserve (Kursk region, Russia): under native steppe vegetation and under 67-yearold bare fallow. The second set of samples was sourced from the Midlands of Kwa-Zulu Natal, South Africa: under pine plantation and under long-term maize monoculture. Soil organic matter was removed by of $30 \%$ hydrogen peroxide $\left(\mathrm{H}_{2} \mathrm{O}_{2}\right)$ treatment for $20-40$ days. The rheological behaviour of the capillary-wetted soil pastes was characterized by amplitude sweep test with the modular compact rheometer MCR-302 (Anton-Paar, Austria). The storage modulus in linear viscous-elasticity range (LVE-range) and crossover of storage modulus and loss modulus were determined. The samples treated with $\mathrm{H}_{2} \mathrm{O}_{2}$ in all cases except the Ferralsol under pine plantation, increased the storage modulus in the LVE-range. It shows more rigid particle interaction due to loss of SOM. The peculiarity of soil under pine plantation is very high resistance to stress in native state and loss of this resistance upon SOM oxidation or removal. We connect this with significant change in particle size distribution upon the $\mathrm{H}_{2} \mathrm{O}_{2}$ treatment. In contrast to other samples, this soil shows significant reduction in coarse silt fraction (from 44.5 to $23.2 \%$ ) and an increase in clay content (from 10.8 to 36.5). We connect the observed differences to the type of organic matter inputs. Unlike the herbaceous vegetation, pine plantations lead to significant accumulation of plant litter on the soil surface. The dissolved organic matter (DOM) is leached out of the litter layer by percolating water. The sorption of DOM (ligand exchange, cation bridges, hydrophobic interactions) on the mineral surfaces contributes to particle aggregation.

Keywords: soil, structure, organic matter, rheology, amplitude sweep test

Kulcsszavak: talaj, szerkezet, szervesanyag, reológia, változó frekvenciájú nyírásvizsgálat
Dolgor KHAYDAPOVA

Associate professor at the M. V. Lomonosov Moscow state University, Department of Soil Science. Specializes in the study of soil structure, soil physics, soil rheology.

Evgeny MILANOVSKIY Leading researcher at M. V. Lomonosov Moscow state University, Department of Soil Science. Specializes in the study of soil organic matter soil structure, soil physics.

LiesI WIESE

Ph.D. student, Stellenbosch University, Department of Soil Science. Specializes in the study of soil organic matter.

Andrei ROZANOV

Senior lecturer, Stellenbosch University, Department of Soil Science. Specializes in the study of soil.

\section{Introduction}

Study of rheological properties of soils are very important for the assessment of soil structure, its resistance to slaking in water and to mechanical stress. The soil structure in turn determines: 1) the structure of the soil pore space as the condition for the optimal development of the plant root system; 2) the soil reaction to compaction under the influence of heavy agricultural machinery; 3) the preservation of organic carbon in occluded form and prevention of its emission into the atmosphere. The soil organic matter represents one of the largest carbon pools in terrestrial ecosystems and affects all soil functions. The formation and stability of soil aggregates is largely due to the presence of the humic substances as "adhesive" [1,4]. Hence, the soil organic carbon (SOC) content strongly affects the soil aggregate stability [10].

Rheological approach to study of the soil structure in recent years has become actively used by researchers as a promising method of quantifying the inter-particle interactions $[2,3,5,6,7,8]$. Baumgarten and Horn [5] were the first to apply the method of amplitude sweep on a rheometer MCR to study soil structure.
In this work we attempt to identify the role of soil organic matter derived from different plant communities on the rheological behaviour of soils of different genesis. The dependence of soil organic matter (SOM) in the top soil horizons of different genesis and under different land use on formation of interpartial structural bonds is analyzed.

\section{Materials}

The first set of soil samples is from the Alekhin Central Chernozemic Reserve (Kursk region, Russia): 1a - Chernozem under native steppe vegetation ( $\left.51^{\circ} 34^{\prime} 19.6^{\prime \prime} \mathrm{N} 36^{\circ} 05^{\prime} 37.3^{\prime \prime} \mathrm{E}\right)$ and $1 \mathrm{~b}$ - Chernozem under bare fallow since $1947\left(51^{\circ} 34^{\prime} 12.6^{\prime \prime} \mathrm{N}\right.$ $\left.36^{\circ} 05^{\prime 2} 2.3^{\prime \prime} \mathrm{E}\right)$. According to the WRB (2006) both soils are Chernozem pachic voronic (Fig.1).

The second set of samples is from the Midlands of KwaZulu Natal, South Africa [11]: 2a - Umbric Ferralsol under pine plantation (Location GPS coordinates S29.23062 E030.32897 $), 2 \mathrm{~b}$ - cultivated Plinthic Ferralsol under longterm maize (Location GPS coordinates monocultureS29.19399 E030.50589 ${ }^{\circ}$ (Fig. 1). The texture of voronic chernozem pachic can be characterized as silt loam, Humic Haplustox under 
forestry plantation - as silt loam and Plinthic Haplustox of farming - as silty clay loam. The studied examples of soil do not contain carbonate salts or lime.

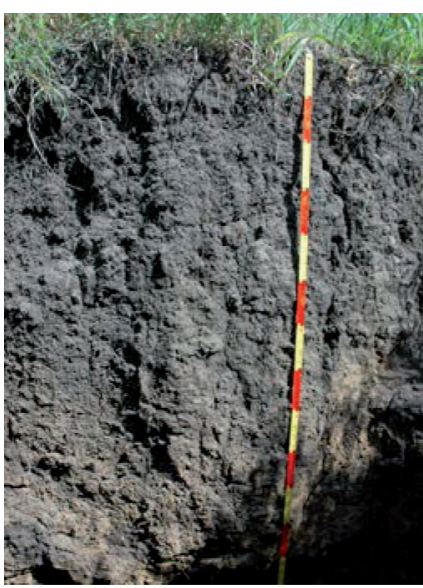

1a)

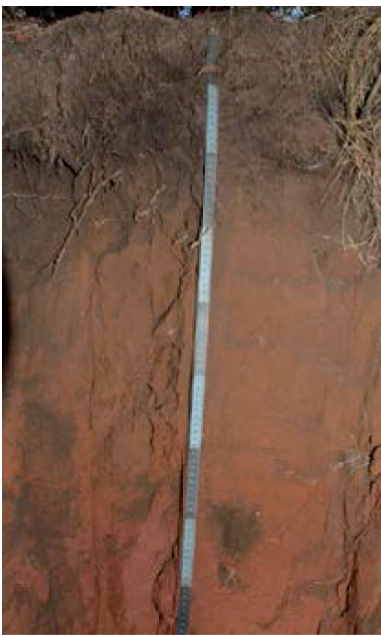

2a)

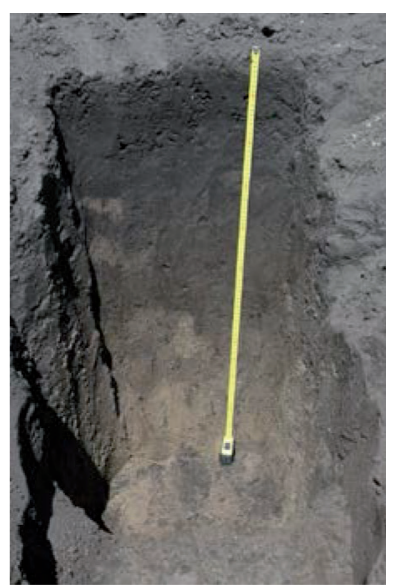

1 b)

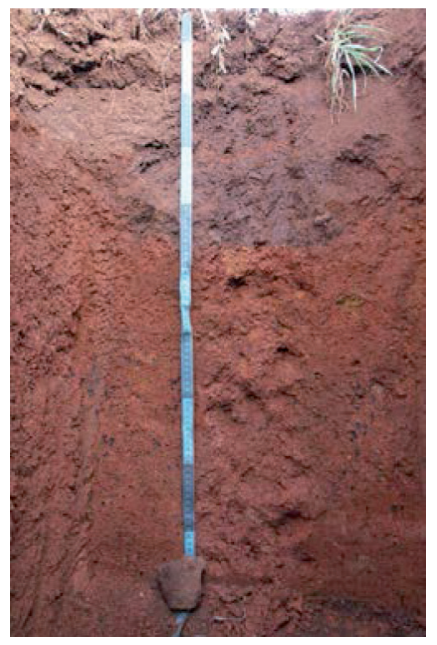

$2 b)$
Fig. 1. Objects of research; 1a) - chernozem under native steppe vegetation 1b) - chernozem old (since 1947) bare fallow; 2a) - Umbric Ferralsol under pine plantation; $2 b$ ) - cultivated Plinthic Ferralsol under long-term maize

1. ábra A kutatás témái; 1a) - Csernozjom természetes sztyeppe vegetáció alatt; 1b) - Öreg csernozjom (1947 óta) parlagon fekvö ugar; 2a) - Umbric Ferralsol fenyö növényzet alatt; 2b) - Müvelt Plinthic Ferralsol kukorica alatt

\section{Methods of research}

Particle size distribution was determined by laser diffraction (Analysette 22 Comfort, Fritsch, Germany) after the dispersion of soil suspension in water by ultrasound for $5 \mathrm{~min}$. Content of total carbon was determined with a $\mathrm{CHN}$ analyzer (Vario EL, Elementar). Organic matter was removed by sample treatment with $30 \%$ hydrogen peroxide $\left(\mathrm{H}_{2} \mathrm{O}_{2}\right)$ for $20-40$ days. Rheological properties of capillary-moistened soil pastes were determined by amplitude sweep test on a modular compact rheometer MCR-302 (Anton-Paar, Austria) [3,5,9]. The following parameters of rheological behavior were obtained: Storage Modulus in the range of linear viscoelasticity (LVE range), the range of linear viscoelasticity, the point of crossover of Storage Modulus and Loss Modulus, which describes the destruction of the elastic structure of the substance (Fig. 2). The studies were conducted in three replicates, average values are presented in this work

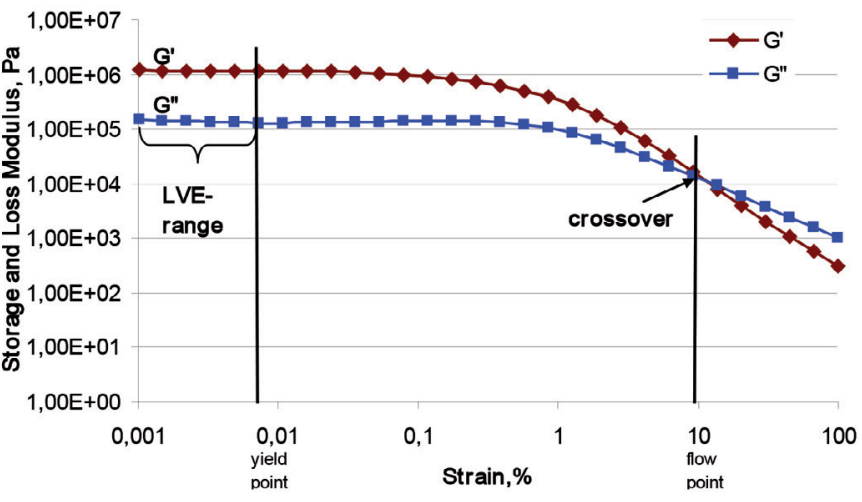

Fig.2. Amplitude sweep test

2. ábra. Változó frekvenciájú nyírásvizsgálat

\section{The obtained results}

The soil organic matter (SOM) content before and after $\mathrm{H}_{2} \mathrm{O}_{2}$ treatment is presented in Table 1. The SOM content after oxidation significantly decreased.

The content of organic matter (\%) before and after oxidation

$\begin{array}{llc}\text { Sample Name } & \begin{array}{c}\text { Content of } \\ \text { organic matter in } \\ \text { initial samples, } \%\end{array} & \begin{array}{c}\text { Content of } \\ \text { organic matter } \\ \text { after oxidation, } \%\end{array}\end{array}$

Chernozem under native steppe vegetation

Chernozem old (since 1947) bare fallow

\section{Umbric Ferralsol under} pine plantation

Cultivated Plinthic Ferralsol under long-term maize

Table 1. Organic matter content of samples 1. táblázat. Minták szervesanyag tartalma

In Chernozem under steppe vegetation after treatment with hydrogen peroxide the content of coarse silt slightly decreased and fine silt and medium silt increased. In Chernozem under long term bare fallow after treatment the content of fine silt increased, but that of coarse silt decreased. In Plintic Ferrasol under long-term maize after treatment the contents of coarse silt decreased and that of medium silt increased slightly.

In contrast to other samples, the soil from pine plantation shows significant reduction in coarse silt fraction (from 44.5 to $23.2 \%$ ) and an increase in clay content (from 10.8 to 36.5 ). In the latter case the coarse silt fraction $(50-10 \mu \mathrm{m}$ fraction) of untreated sample consists to a large extent of clay-SOM-clay micro-aggregates resistant to $400 \mathrm{~J} \mathrm{ml}^{-1}$ of ultrasonic dispersion energy (Branson Ultrasonics, USA). SOM oxidation leads to disaggregation and changes in particle size distribution (Fig. 3.c). We see that in all cases (Fig. 3) there was a decrease in the content of coarse silt, which shows the removal of organic matter caused the destruction of microaggregates and the increase in the proportion of the finer fractions.

In all samples after removal of OM the storage modulus in the LVE-range increased, except for the ferralitic soil from the pine forest (Fig. 4). 

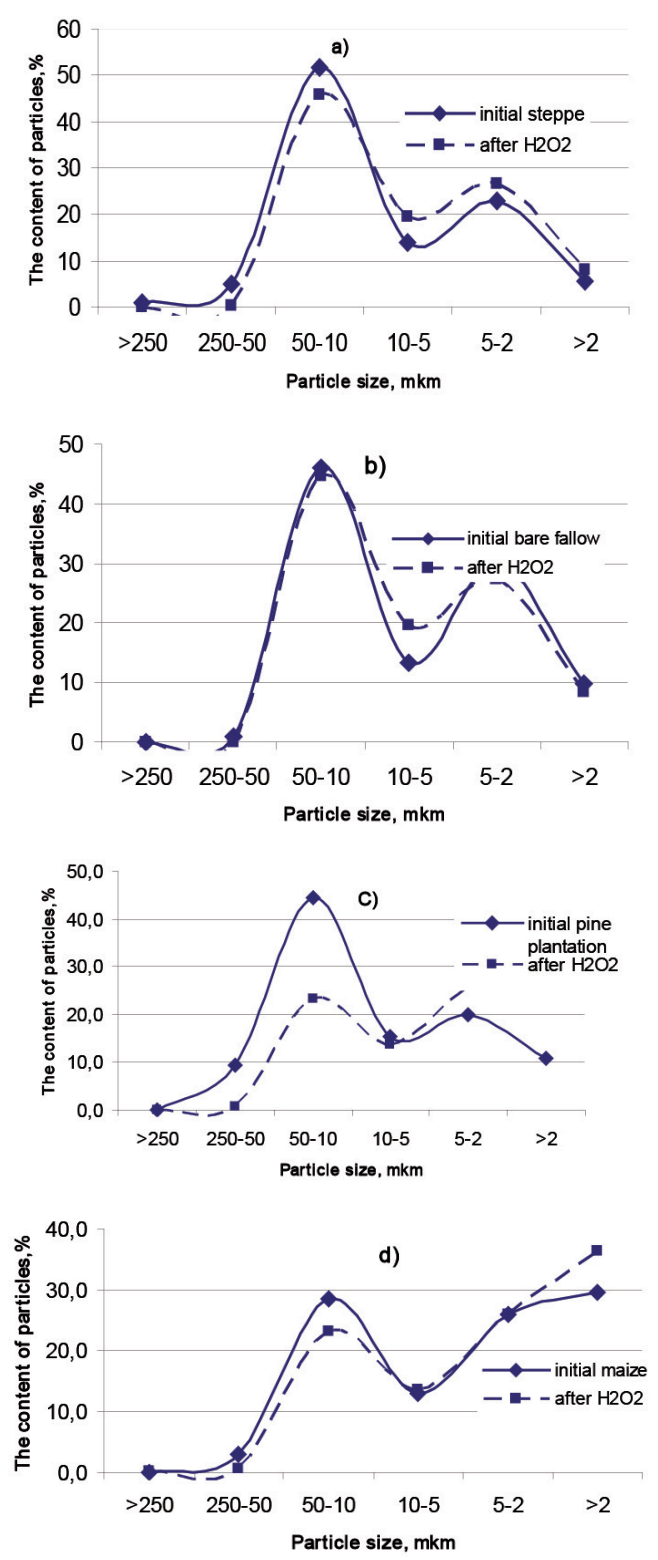

Fig. 3. Particles size distributions before and after oxidation of organic matter a) in Chernozem under steppe vegetation; $b$ ) in Chernozem under long term bare fallow; c) in Ubric ferralsol under pine plantation; d) in Plinthic ferralsol under long term miaze.

3. ábra Szemcseméret eloszlás a szervesanyag oxidálása elött és után; a) - Csernozjom természetes sztyeppe vegetáció alatt; b) - Öreg csernozjom (1947 óta) parlagon fekvő ugar; c) - Umbric Ferralsol fenyö növényzet alatt; d) - Müvelt Plinthic Ferralsol kukorica alatt

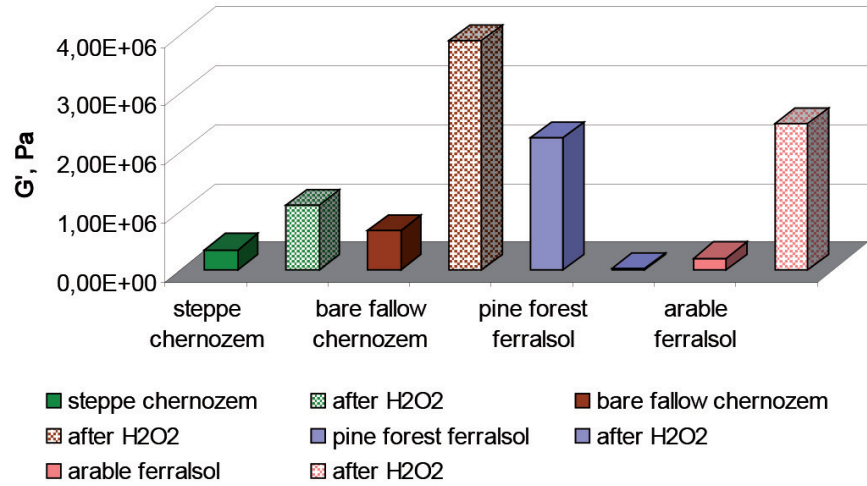

Fig. 4. Storage modulus before and after $\mathrm{H}_{2} \mathrm{O}_{2}$ treatment in Chernozems and Ferralsols 4. ábra Storage modulus $\mathrm{H}_{2} \mathrm{O}_{2}$ kezelés elött és után Csernozjom és Ferralsol mintákban
Possible strengthening of inter-particle contacts in all the samples, except the soil from pine forest occurred due to the development of direct contacts between the rigid particles in the absence of SOM. The decrease of storage modulus in the soil from the pine plantation may be due to a significant increase in the content of the fine silt and clay fractions after removal of SOM. It accordingly absorbs more water and reduces strength of inter-particle contacts. A significant increase in the modulus of elasticity in the arable soils likely associated with a significant decrease in the content of SOM after oxidation or removal. The increase in the strength of bonds between soil particles probably causes block-like soil structure.
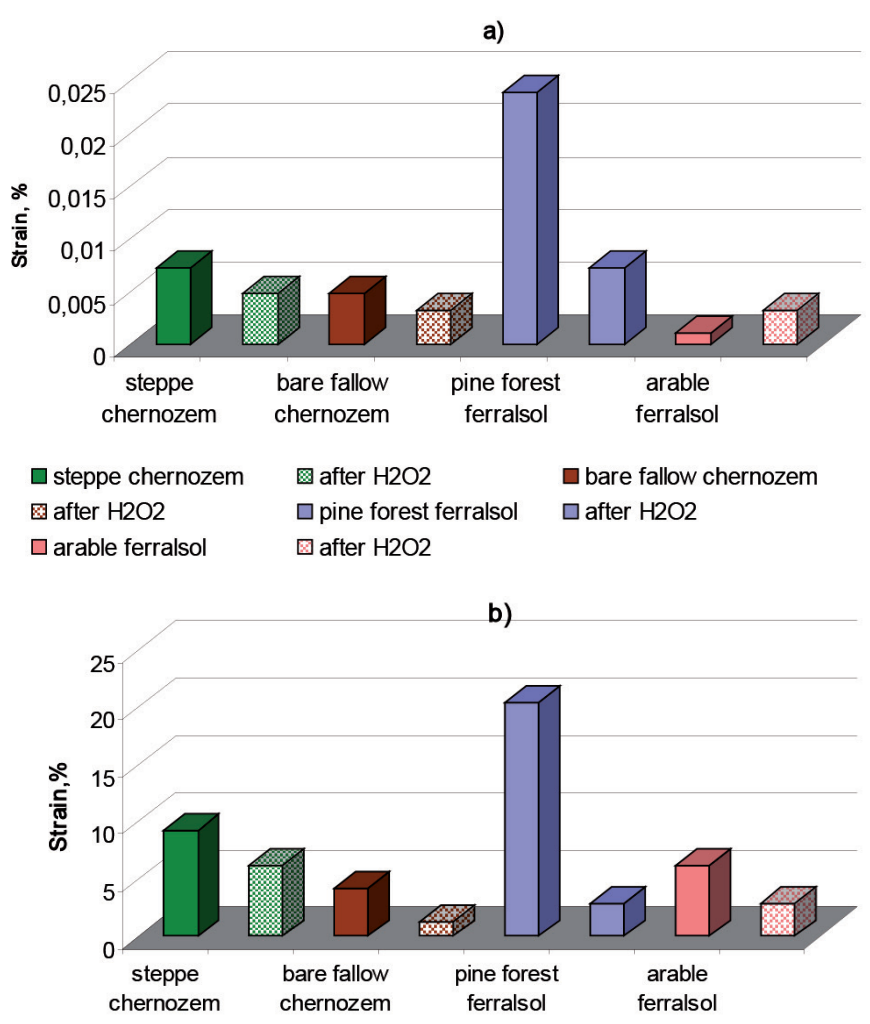

\footnotetext{
$\square$ steppe chernozem

国 after $\mathrm{H} 2 \mathrm{O} 2$

因 after $\mathrm{H} 2 \mathrm{O} 2$

$\square$ bare fallow chernozem

$\square$ arable ferralsol

$\square$ pine forest ferralsol

$\square$ after $\mathrm{H} 2 \mathrm{O} 2$
Fig. 5. Linear viscoelastic (LVE) range - a) and crossover - $b$ ) of soils before and after treatment $\mathrm{H}_{2} \mathrm{O}_{2}$
5. ábra Lineárisan viszkoelasztikus (LVE) tartomány - a) és crossover - b) $\mathrm{H}_{2} \mathrm{O}_{2}$ kezelés elött és után
}

The values of LVE-range in all variances of soils after removal OM went down, also as well as crossover. This means that the soil structure after the SOM removal became less resistant to stress.

The soil under pine forests is characterized by high values for all measured rheological parameters.

We connect the observed differences to the type of organic matter inputs. Unlike the herbaceous vegetation, pine plantations lead to significant accumulation of plant litter on the soil surface. The dissolved organic matter (DOM) is leached out of the litter layer by percolating water. The sorption of DOM (ligand exchange, cation bridges, hydrophobic interactions) on the mineral surfaces contributes to particle aggregation. 


\section{Conclusions}

The increase in the strength of bonds between soil particles probably causes block-like soil structure. In the absence of SOM in interaction between soil particles is more rigid, samples of soil types become less plastic, destruction of structural bonds happens at smaller loadings.

The distinct rheological behavior of soil from pine plantations is manifested as very high resistance to loadings in its initial state and significant loss of stability after SOM oxidation.

The quality of organic matter due to different plant origin has an effect on the processes of micro-aggregation and consequently on the rheological behaviour of soils. The established differences in the rheological behavior of the studied soils from different locations and land uses may be associated with the type of organic inputs.

\section{Acknowledgments}

The study was supported by Russian Fond of Basic Research - project № 16-04-01111 The laboratory work utilized the equipment purchased by the MSU Development Program. The sampling in South Africa was funded by the South African National Research Foundation (NRF) through the Department of Science and Technology/NRF Green Landscapes project, the Applied Centre for Climate \& Earth Systems Science (ACCESS) programme, as well as the NRF Thuthuka programme. The funding sources had no involvement in the study design, collection, analysis and interpretation of data, writing the report, or submitting the article for publication.

\section{References}

[1] Voronin, A. D.: Strukturno-funktsionalnay gidrofizika pochv (1984), Izdatelstvo MGU, p.204.

[2] Khaydapova, Dolgor - Yurevich Milanovskiy, Evgeny - Victorovich Shein, Evgeny (2013): Impact of Antropogenic Load on Rheologocal Properties of Typical Chernozems (Kyrsk Region, Russia). Advances in geoecology 42: Soil Degradation, Catena Verlag GMBH, Reiskirchen, Germany, pp. 62-71.

[3] Khaidapova, D. D. - Chestnova, V. V. - Shein, E. V. - Milanovskii, E. Yu.: Rheological properties of typical chernozems (Kursk Oblast) under different land uses, Eurasian Soil Sci., 2016, vol. 49, no. 8, p. 890 https://doi.org/10.1134/S1064229316080044

[4] Kachinskiy, N. A.: Soil physics (1965) Visshaya shkola, Moscow, p.323.

[5] Markgraf, W. - Horn, R. - Peth, S. (2006): An Approach to Rheometry in Soil Mechanics: Structural Changes in Bentonite, Clayey and Silty Soils. Soil and Tillage Research. No 91, pp. 1-14.

https://doi.org/10.1016/j.still.2006.01.007

[6] Markgraf, W. - Watts, C. W. - Whalley, W. R. - Hrkac, T. - Horn, R.: Influence of organic matter on rheological properties of soil. Applied Clay Science. 2012, V. 64, P. 25-33. https://doi.org/10.1016/j.clay.2011.04.009

[7] Pertile, P. - Reichert, J. M. - Gubiani, P. I.: Rheological parameters affected by water tension in subtropical soils, Rev. Bras. Cienc Solo, 2016, vol. 40, p. e0150286 https://doi.org/10.1590/18069657rbcs20150286

[8] Baumgarten, W. - Horn, R. (2013): Assessing soil degradation by using a scale-spanning soil mechanical approach: A review. Advances in geoecology 42: Soil Degradation, Catena Verlag GMBH, Reiskirchen, Germany, pp. 1-61.

[9] Mezger, T. (2011): The Rheology Handbook - For users of rotational and oscillatory rheometers. $3^{\text {rd }}$ revised edition, Vincentz, Hannover, Germany, $252 \mathrm{p}$.

[10] Tisdall J. M. - Oades J. M. (1982): Organic matter and water-stable aggregates in soils. Journal of Soil Sci. V.33,p.141-163 https://doi.org/10.1111/j.1365-2389.1982.tb01755.x

[11] Wiese, Liesl - Ros, Ignacio - Rozanov, Andrei - Boshoff, Adriaan Clercq, Willem de - Seifert, Thomas (2016): An approach to soil carbon accounting and mapping using vertical distribution functions for known soil types. Geoderma 263, pp. 264-273

https://doi.org/10.1016/j.geoderma.2015.07.012

$\underline{\text { Ref.: }}$

Khaydapov, Dolgor - Wiese, Liesl - Rozanov, Andrei - Milanovskiy, Evgeny: Rheological parameters of some soil samples before and after $\mathrm{H}_{2} \mathrm{O}_{2}$ treatment

Építőanyag - Journal of Silicate Based and Composite Materials, Vol. 70, No. 2 (2018), 38-41. p.

https://doi.org/10.14382/epitoanyag-jsbcm.2018.8

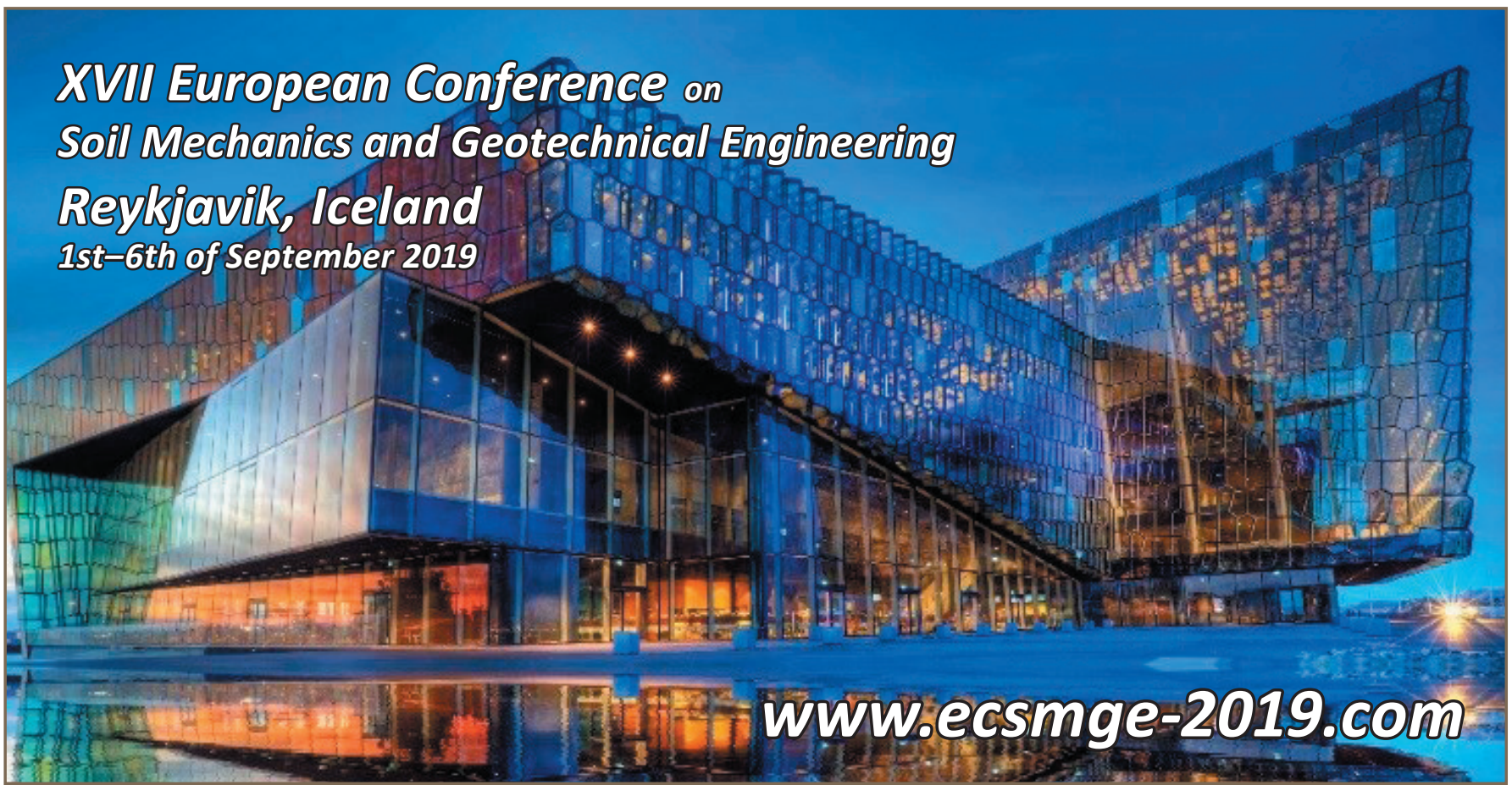

